most popular contemporary lesbian novels which none the less recognizes that postmodernism cannot do justice to Schulman's work. The disjuncture between feminism - a political force desirous of material change - and postmodernism - a critique with no theory of political resistance - is certainly the chasm around which this collection picks its way, albeit for the most part elegantly and with self-awareness. There is a fine line between such self-awareness and self-consciousness, though, with the one leading to subtle and critical analysis and the other to a kind of trendy intellectual anxiety (as evidenced by those ubiquitous (parenthetical) qualifiers) which can seem, ultimately, to imply wilful disengagement.

New Lesbian Criticism gathers pace through the book; Katie King's 'Audre Lorde's lacquered layerings' is a powerful engagement with both literary ideology and feminist practice which perhaps points a way beyond the postmodernism-versusfeminism impasse. Angela Weir and Elizabeth Wilson's highly readable 'The Greyhound bus station and the evolution of lesbian popular culture' posits lesbian romantic fiction (by Ann Bannon, Reed Marr, March Hastings, Taylor Frances among others) as a potent symbol of the 'Janus-faced fifties', radical and startling in their exposition of an entirely new phenomenon - a vibrant lesbian and gay culture - but conformist in their insistence that sexuality represents the kernel of the self. Their analysis of the potency and poignancy of the $1950 \mathrm{~s}$ butch '[combining] the vulnerable with the invulnerable simultaneously' has strong resonances with the 'true-life' stories in Joan Nestle's recent $A$ Persistent Desire - a femme-butch reader (Alyson, 1992). Why is it that butch and femme has elicited so much more insightful and humane lesbian cultural analysis than any other aspect of lesbian sexual expression?

Gillian Spragg's delightful 'Hell and the mirror' charts Jane Rule's use of metaphor in Desert of the Heart through close analysis of her 'polemical reconstruction' of various hells as conceived in the Divine Comedy, the Book of Genesis and The Well of Loneliness. The following through of this analysis with regard to the subsequent film Desert Hearts, in a similar vein to Hilary Hinds's analysis of Oranges are Not the Only Fruit's journey from lesbian cult to BBC drama via literary plaudit, would make for doubly interesting reading.

In a sense Inversions and New Lesbian Criticism represent the Janus-face of nineties lesbian politics and theory; the one looking back to identity politics, the other looking forward, albeit tentatively at times, to a 'rich and rewarding world at the intersection of postmodern criticism and feminist politics'.

\section{Sara Dunn}

Odd Girls and Twilight Lovers: A History of Lesbian Life in TwentiethCentury America

Lillian Faderman

Penguin Books: New York 1992 ISBN $0140171223 £ 9.99 \mathrm{Pbk}$

In 1981, Lillian Faderman's book Surpassing the Love of Men
What a Lesbian Looks Like: Writings by Lesbians on their Lives and Lifestyles

National Lesbian and Gay Survey

Routledge: London 1992

ISBN0 $415081009 £ 9.99 \mathrm{Pbk}$

(Junction Books) was published, and I bought it for the title alone. Having 
come out as a lesbian in the context of British feminist politics the previous year, I found Surpassing the Love of Men an important book. Big, detailed and scholarly, it took lesbians and lesbianism seriously as subjects for historical study. Here was one of an increasing number of lesbian feminists who were doing research work on our own terms, trying to find out what those terms were, and who 'we' were. Both of the books reviewed here are still addressing similar questions: what is the nature of lesbian life in the twentieth century, and what is a lesbian anyway?

The main message of both texts is that lesbian experience is extremely diverse, always set in historical and political context, and that there is no 'one' unitary lesbian subject. The strategies adopted for lesbian survival have varied in embattled conjunction with the forms of oppression we face. Central to both lesbian oppression and lesbian resistance/survival is the construction of lesbianism and the lesbian: both books document different histories (in Britain and in North America) of this battle over lesbian identity. This is not just a matter of how lesbianism should or could be defined, but a struggle over who (i.e., which social forces and social groups) will control that process of definition, of naming and of explanation. As a 'deviant' status, lesbianism always appears to require an explanation in a way that heterosexuality does not.

Odd Girls and Twilight Lovers examines women's experiences of love for other women in the USA, drawing on various historical texts and interviews with 186 women about their lives. Lillian Faderman emphasizes that since the category of lesbian (or 'female sexual invert') was only formulated during the second half of the nineteenth century, women who loved other women in the twentieth century were compelled for the first time to understand their experiences in relation to the notion of lesbianism. Much of the book deals with the diversity of women's responses to their situation, both individually and culturally, and the importance of 'race', class, age and historical/political context in shaping women's perspectives. Faderman points to the central contradiction of lesbian identification: the dilemma involved in naming oneself in terms of a concept which emerged from a deeply oppressive set of institutions.

Odd Girls examines the shift from the prevalence of 'romantic friendships' between women in the early twentieth century to the growing use of the medicalized terminology of 'sexual inversion' following the work of early sexologists. Faderman considers the rise of 'lesbian chic' in the 1920s, looking at the lives of working- and middle-class lesbians, and Black (i.e., AfricanAmerican) lesbians in Harlem. She traces the practice of bisexuality as a form of experimentation and compromise into the 1930 s and looks at the impact of World War II in helping to forge a lesbian subculture.

Following the witch-hunts of the McCarthy years, Faderman argues that lesbian subculture(s) began to expand during the 1950 s and 1960 s, focused around the bar scene for working-class and young lesbians. She presents the prevalence of butch/femme roles as a consequence of that particular historical context, prior to the period of gay, lesbian and feminist revolutionary activity during the 1960 s and 1970 s.

It is here that the book becomes more controversial, as Faderman considers the lives of radical and revolutionary lesbian feminists in the $1970 \mathrm{~s}$, forging a Lesbian Nation and lesbian communities, and fragmenting in factional battles by the 1980 s. I found myself reading the book differently from this point onwards. Until the chapters on the growing connexions between lesbianism and feminism, I read as a sympathetic and enthralled 
'outsider'; this was riveting stuff, but it had few resonances with my own experiences. Although I was not in the USA during the 1970s, and I did not identify as lesbian at that time, the chapters on that period are more familiar. I had read some of the books and been involved in some (similar) arguments in Britain during the early 1980 s. I began to read as an 'insider', but a perplexed one.

The book presents 'radical lesbian-feminists' as 'extremists' whose main contribution to lesbian and gay politics appeared to be to allow the demands of more 'moderate' activists to appear 'tame' by comparison. In political terms, this could be seen as one function of radical lesbian feminism, but it is Faderman's analysis of the conflicts which she presents as inherent in lesbian feminism and as tearing the movement and the culture apart where my greatest difficulties occurred.

Faderman states that 'the (lesbian feminist) community opened itself to criticsm from all minority voices' (236, my insertion and emphasis). There is another possible perspective here though. Lesbians of colour, working-class lesbians, lesbians with disabilities, older and younger lesbians all continued to make the arguments they had been making for some years about exclusion, ethnocentrism, racism, élitism and so on. Anglo, middleclass, able-bodied lesbian feminists, who had tended to dominate the movement in a similar way to the pattern in the 'straight' feminist movement, had to listen: they could no longer manage to ignore or suppress these 'minority voices', and the movement changed radically as a consequence of this. For Faderman, the subsequent attempts to 'reconcile differences' meant that 'vast amounts of energy were wasted on conflicts' (236, my emphasis). If such debates (which were undeniably heated, and which Faderman refers to using the metaphors of battle) involved serious attempts to recognize differences between lesbians and to challenge some of the inequalities within the movement, then such energies need not be seen as totally 'wasted'.

Odd Girls has been castigated (by E. Miller in a Trouble and Strife review, No. 25, 1992) for the way in which Faderman treats the increasing diversity and moderation of 1990s lesbian life, and especially SM sex, with relative enthusiasm. Understanding where glamour dykes, lipstick lesbians and the rise of SM come from in political and historical terms is just as vital a project as understanding the emergence of radical lesbian feminism. What I found most perplexing about Odd Girls was its ambivalence on the politics of the research process. Faderman does write herself in to the text on occasions, but she implicitly adopts a relatively distanced and 'impartial' perspective. Most feminist researchers would argue that any attempt at impartiality is misguided. Her treatment of radical lesbian feminism and lesbian life in the 1980 s and 1990 s make it clear that Faderman is not impartial. This is not necessarily a problem. What is confusing is her relative reluctance to deal with this issue in the text, or to acknowledge more clearly that her version is one of many. The use of the third person throughout most of the text only reinforces the sense that 'this is how things really were!'.

What a Lesbian Looks Like is a less obviously controversial book, but it also presents a detailed and readable account of a diverse range of lesbians' experiences in contemporary British society. The book is a continuation of the Mass Observation Surveys that were first conducted in Britain during the 1930s and 1940s. Anonymous contributors (or 'observers') submitted material to the National Lesbian and Gay Survey from 1985, and the book presents a selection of extracts from this archive, with a pseudonym above 
each piece. Chapters are entitled 'Beginnings', 'Kin', 'Becoming', 'Uniforms', 'Out', 'Mind and body', 'Together', 'Power and community', and there is minimal editorial text between each extract.

Reading What a Lesbian Looks Like emphasizes the authenticity and diversity of lesbian voices in Britain. The lack of any editorial comment or context to the extracts has particular effects. The extracts were presumably selected and organized into chapters by the NLGS team, but very little information is available on how this process occurred. Was it simply on the basis of the most common themes in the Survey submissions, or were particular themes given special priority, and if so, why? Presenting the extracts in this way means the lack of any historical or political context outside of the extracts themselves, which can produce a sense of listening to a set of dislocated voices.

So what do these books tell us about lesbians' lives in Britain and the USA? They present an enormous diversity of stories and experiences in a readable and detailed form. They also imply that as Lillian Faderman argues: 'The criterion for identifying oneself as a lesbian has come to resemble the liberal criterion for identifying oneself as a Jew: you are one only if you consider yourself one' (5). The political implications of this definition of (post1920s) lesbianism and of the diversity of lesbians' lives are complex and the focus for continuing debate in lesbian-feminist groups in Britain, the USA and around the world.

\section{Christine Griffin}

\section{The Inward Gaze: Masculinity and Subjectivity in Modern Culture}

\section{Peter Middleton}

Routledge: London 1992

ISBN $0415073286 £ 35.00 \mathrm{Hbk}$;

ISBN $0415073278 £ 11.99 \mathrm{Pbk}$

\section{Male Subjectivity at the Margins}

\section{Kaja Silverman}

\section{Routledge: London 1992}

ISBN0 $415904188 £ 40.00 \mathrm{Hbk}$; ISBN $0415904196 £ 12.99 \mathrm{Pbk}$

Given the current ascendancy of appearance and political correctness over radical action it is perhaps no surprise that what most distinguishes these two books is the confidence of Silverman's attention to absence compared to the diffidence of Middleton's account of the presence of the marks of masculinity.

It is, as Middleton observes, no longer acceptable for men confidently to affirm 'I think, therefore I am'. Self-reflection cannot authenticate itself. To think otherwise, as modernism and feminism expose, is mere male conceit. Hence Middleton's wariness about his sex's tendency to universalize the results of their introspection, especially given its scant regard for emotion.

Hence too his apologetic reminiscences of his own boyhood trainspotting, of another youth's pocketful of male insignia, of the perilous path steered by Marvel Comic heroes between beast and robot so much is bodily contact between them brutalized and all other feeling masked or expelled in inarticulate neologism - the fodder, Middleton says, boys are fed to fill the gap left by men's absence from the home.

How he deplores his sex for quitting the vulnerabilities of childhood for an impersonal version of adulthood as described in James Joyce's Portrait of the Artist as a Young Man. How he objects to the canonization of Yeats's male flight from the commonplace into the 